\title{
Effect of plant spacing and nitrogen on yield of transplant aman rice var. BRRI dhan 52
}

\section{A. Haque, A. H. M. Razzaque, A. N. A. Haque and M. A. Ullah}

Bangladesh Institute of Nuclear Agriculture (BINA), Bangladesh Agricultural University campus, Mymensingh-2202, Bangladesh

\begin{abstract}
An experiment was conducted at the Agronomy Field Laboratory, Bangladesh Agricultural University, Mymensingh, during the period from 10 July 2012 to 15 December 2012 to investigate the effect of plant spacing and nitrogen levels on yield and attributes yield of transplant aman rice cv. BRRI dhan52. The experiment comprised of four plant spacing viz. $25 \mathrm{~cm} \times 20 \mathrm{~cm}, 25 \mathrm{~cm} \times 15 \mathrm{~cm}, 20 \mathrm{~cm} \times 20 \mathrm{~cm}$ and $20 \mathrm{~cm}$ $\times 15 \mathrm{~cm}$, and five nitrogen levels viz. $0,40,80,100$ and $140 \mathrm{~kg} \mathrm{~N} \mathrm{ha}^{-1}$. BRRI dhan52 was used as planting material. Results revealed that plant spacing and $N$ levels had significant effect on the studied crop characters and yield. The plant height, number of total tillers and effective tillers hill-1, grains panicle ${ }^{-1}$, grain and straw yields increased with increasing plant spacing and $N$ levels. The highest plant height, number of total tillers and effective tillers hill-1 and grains panicle ${ }^{-1}$ was observed in the widest spacing of $25 \mathrm{~cm} \times 20 \mathrm{~cm}$ resulting, the highest grain yield followed by $20 \mathrm{~cm} \times 20 \mathrm{~cm}$. In contrast, the closest spacing of $20 \mathrm{~cm} \times 15 \mathrm{~cm}$, produced the lowest values of the above mentioned plant parameters and also showed the lowest grain yield. The longest plant, highest number of total, effective tillers hill-1, grains panicle ${ }^{-1}$, grain and straw yields were observed with $100 \mathrm{~kg} \mathrm{~N} \mathrm{ha}^{-1}$ followed by $140 \mathrm{~kg} \mathrm{~N} \mathrm{ha}^{-1}$. On the other hand, the shortest plant, lowest number of total tillers and effective tillers hill-1, grains panicle-1, grain and straw yields were observed with no nitrogen and the non-effective tillers hill-1 and sterile spikelet's panicle ${ }^{-1}$ were recorded the highest. In regard to interaction effect of spacing and $N$ levels, the highest plant height, number of total and effective tillers hill-1 were observed in the widest spacing of $25 \mathrm{~cm} \times 20$ $\mathrm{cm}$ with $100 \mathrm{~kg} \mathrm{~N} \mathrm{ha-1}$ and resulting the highest grain yield. The lowest values of the above parameters were recorded in the narrowest plant spacing, $20 \mathrm{~cm} \times 15 \mathrm{~cm}$ with no nitrogen application. Based on the experimental results, it may be concluded that $25 \mathrm{~cm} \times 20 \mathrm{~cm}$ spacing with $100 \mathrm{~kg} \mathrm{~N} \mathrm{ha}^{-1}$ would be the best treatments combinations regarding yield and yield attributes of BRRI dhan52.
\end{abstract}

Key words: Transplant Aman rice, nitrogen levels, plant spacing, BRRI dhan52 and rice yield

Please cite this article as: Haque, M. A., Razzaque, A. H. M., Haque, A. N. A. and Ullah, M. A. (2015). Effect of plant spacing and nitrogen on yield of transplant aman rice var. BRRI Dhan52. Journal of Bioscience and Agriculture Research 04(02): 52-59.

This article is distributed under terms of a Creative Common Attribution 4.0 International License

\section{Introduction}

Rice (Oryza sativa L.) is the major food crop of Bangladesh. Area and production of rice in Bangladesh are about 10.37 million hectares and 25.16 million tons, respectively with an average yield of only 2.43 t ha-1 ${ }^{-1}$ Among the groups, transplanted Aman (T. Aman) rice covers about $50.92 \%$ of total rice area and 
contributes to $39.03 \%$ of total rice production in the country (Anonymous, 2009). The possibility of horizontal expansion of rice production area has come to a standstill (Hamid, 1991). Rice is grown in three cropping seasons in our country viz Aus, Aman, Boro rice. Total rice area in Bangladesh are 1112.87, 5645.64 and 4770 thousands hectare in Aus, Aman, Boro seasons respectively (BBS, 2011). Among these three rice crops; Transplant aman rice covers about 5645.64 thousands hectares of the total and contributes 12791.5 thousands metric tons of the total rice production in the country (BBS, 2011). For the unplanned population planning the area under rice cultivation in the country is decreasing day by day. Therefore, to get self-sufficiency in rice production it is imperative to increase rice yield in the country. Bangladesh is an agro-based country, earns about $23.46 \%$ of her gross domestic products (GDP) from agriculture (Kiron, 2003). Bangladesh is facing a chronic shortage of food over the year due to high population pressure, and the total rice area is continuously declining due to urbanization and industrialization. Moreover, some rice growing areas are now being used for cultivation of fishes as it is more profitable than that of rice production. Now it has become necessary to ensure food security for the increasing population. The soil and climate of Bangladesh are favorable for rice cultivation throughout the year but the yield of this crop is much below the potential level. The reasons are manifolds; some are varietals, some are technical and some are socio-economic in nature. Scientists in the National Agricultural Research System have been continuing their efforts to increase the yield per unit area through effective management practices. Proper management practices are the most effective means for increasing yield of Aman rice. Efficient fertilizer management gives higher yield of crop and reduces fertilizer cost (Hossain and Islam, 1986). Optimum dose of nitrogen fertilization plays a vital role in growth and development of rice plant. Its growth is seriously hampered when lower dose of nitrogen is applied, which drastically reduces yield (BRRI, 1990). On the other hand, excessive nitrogen fertilization encourages excessive vegetative growth which makes the plant susceptible to insect, pest and diseases, which ultimately reduces yield. So, it is essential to find out the optimum rate of nitrogen application for efficient utilization of this element by the plants for better yield. BRRI (1990) reported that nitrogen has a positive influence on the production of effective tillers plant ${ }^{-1}$.

Plant spacing is also an important factor that needs to be considered during transplanting of rice. Rice plants compete among themselves for space, nutrients, water, sunlight, air another factors such as photosynthesis and respiration under densely planted condition. Proper spacing may help receive maximum leaf Area Index (LAI), light interceptions etc. are better for photosynthesis as well as yield of rice. Some of them use very closer plant spacing and others are using wider plant spacing. Optimum plant spacing ensures the plants to grow properly both in their aerial and underground parts through efficient utilization of solar radiation and nutrients (Miah et al., 1990). BRRI dhan52 is a new variety released by BRRI which can be grown in the lower regions and flooded regions of Bangladesh, because it is a submergence tolerant variety. As if, it is submergence tolerant variety so can be grown in the lower regions and flooded regions of Bangladesh for the increasing production of rice. It can play an important role to cover the shortage of food and ensuring food security. The experiment was conducted to investigate the effect of plant spacing and nitrogen levels on the yield of transplant Aman rice cv. BRRI dhan52

\section{Materials and Methods}

The experiment was conducted at the Agronomy Field Laboratory of Bangladesh Agricultural University, Mymensingh during the period from 10 July 2012 to 15 December 2012 to investigate the effect of plant spacing and nitrogen levels on the yield of transplant Aman rice cv. BRRI dhan52. The experimental site belongs to the Agro-ecological zone of the Old Brahmaputra Floodplain (AEZ 9) having dark grey soil (UNDP and FAO, 1988). The experimental area has sub-tropical climate characterized by heavy rainfall during the months from June to September and scanty rainfall during the rest of the year. The experiment comprised of four plant spacing viz. $25 \mathrm{~cm} \times 20 \mathrm{~cm}, 25 \mathrm{~cm} \times 15$ $\mathrm{cm}, 20 \mathrm{~cm} \times 20 \mathrm{~cm}$ and $20 \mathrm{~cm} \times 15 \mathrm{~cm}$, and five nitrogen levels viz. 0, 40, 80, 100 and $140 \mathrm{~kg} \mathrm{Nha}^{-1}$. The variety BRRI dhan52 used as a planting material. The experiment was laid out in a randomized complete block design with three replications. The size of a unit plot was $(4.0 \mathrm{~m} \times 2.5 \mathrm{~m})$. The distances between replications and between plots were $1 \mathrm{~m}$ and $0.75 \mathrm{~m}$ respectively. Intercultural operations such as gap filling, weeding, crop protection measures, mater management were done as when as

Corresponding author emails: mahaquebina@gmail.com (Haque, M. A.) / maullah09@gmail.com (Ullah, M. A.) eISSN: 2312-7945, (C) Haque et al. (2015), Research paper 
required. Data were collected on plant height, total tillers hill-1 ${ }^{-1}$ effective fillers hill- $^{-1}$, non-effective fillers hill-1, panicle length, total grains panicle ${ }^{-1}$, number of unfilled grains panicle ${ }^{-1}$, number of filled grains panicle-1, 1000-grain weight, grain yield, straw yield, biological yield, harvest index at the time of harvest. All the collected data were analyzed by following the analysis of variance (ANOVA) technique and mean differences were adjudged by Duncan's Multiple Range Test (DMRT) (Gomez and Gomez, 1984) using a computer operated statistical programme named MSTAT-C.

\section{Results and Discussion}

\section{Effects of plant spacing}

Plant height and effective tiller number decreased with decreasing plant spacing whereas reverse trend was observed in number of non-effective tillers hill- ${ }^{-1}$. The highest plant height $(108.3 \mathrm{~cm})$ and effective tiller (5.29) was recorded in wider spacing of $25 \mathrm{~cm} \times 20 \mathrm{~cm}$. However, spacing showed insignificant effect on number of total tillers hill-1 in $25 \mathrm{~cm} \times 20 \mathrm{~cm}$ (7.12), $25 \mathrm{~cm} \times 15 \mathrm{~cm}$ (7.14) and 20 $\mathrm{cm} \times 20 \mathrm{~cm}$ (7.16) except the spacing $20 \mathrm{~cm} \times 15 \mathrm{~cm}$ (6.73). The similar result was found from the findings of Miah et al. (1990). In contrast, closer spacing, $20 \mathrm{~cm} \times 15 \mathrm{~cm}$, performed the lowest plant height and number of effective tiller hill-1. Panicle length, number of filled grains panicle ${ }^{-1} 1000$-grain weight decreased significantly with decreasing plant spacing. On the other hand, number of unfilled grain increased with decreasing plant spacing. The highest panicle length (24.63) and number of effective tillers hill-1(5.29) were recorded in wider spacing of $25 \mathrm{~cm} \times 20 \mathrm{~cm}$ while the lowest panicle length $(22.58 \mathrm{~cm})$ and number of effective tillers hill-1 $(4.60)$ were recorded in closer spacing 20 $\mathrm{cm} \times 15 \mathrm{~cm}$ (Verma et al. (2002). Similarly, biological yield and grain yield decreased with decreasing plant spacing. The highest biological ( 9.69 tha $\left.^{-1}\right)$ and grain yield (4.247 tha-1) were observed in wider spacing of $25 \mathrm{~cm} \times 20 \mathrm{~cm}$ and the lowest was recorded in the closer spacing of $20 \mathrm{~cm} \times 15 \mathrm{~cm}$. Harvest index was greater in closer spacing (44.63) than the wider spacing (43.46).

\section{Effect of nitrogen levels}

Different levels of $\mathrm{N}$ application showed a profound influence on morphological, yield and yield attributes and harvest index of T. Aman rice. Results revealed that plant height, total tiller number, effective tiller number and panicle length increased with increasing nitrogen doses till $100 \mathrm{~kg} \mathrm{~N} \mathrm{ha}^{-1}$ followed by a decline. The plant height was influenced significantly due to application of nitrogen level (Table 02). The highest plant height $(107.7 \mathrm{~cm})$ was obtained from $140 \mathrm{~kg} \mathrm{~N}^{-1}$ while the shortest plant height $(102.8 \mathrm{~cm})$ was from control treatment (Table 02). Excess of nitrogen in the treatment of $140 \mathrm{~kg} \mathrm{~N} \mathrm{ha}{ }^{-1}$ might have encouraged more vegetative growth of plant producing the tallest plant Chopra and Chopra (2004). Rate of nitrogen had significant effect on the production of effective tillers hill- $^{-1}$. The highest number of effective tillers hill-1 (5.450) was obtained from $100 \mathrm{~kg} \mathrm{~N} \mathrm{ha}^{-1}$ followed by $140 \mathrm{~kg} \mathrm{~N} \mathrm{ha}^{-1}$. The lowest number of effective tillers hill-1 (4.363) found from control treatment or no nitrogen. The highest number of non-effective tillers hill-1 $(2.458)$ was obtained from $0 \mathrm{~kg} \mathrm{~N} \mathrm{ha}^{-1}$ and the lowest number of non-effective tillers hill-1 (1.7) was found from $100 \mathrm{~kg} \mathrm{~N} \mathrm{ha}^{-1}$. Nitrogen rate had significant effect on the number of total tillers hill-1. The highest number of total tillers hill-1 (7.250) was obtained from $140 \mathrm{~kg} \mathrm{~N} \mathrm{ha}^{-1}$ and followed by $100 \mathrm{~kg} \mathrm{~N}^{-1}$. The lowest number of total tillers hill-1 (6.820) was found from control. This result is in agreement with the findings of Idris and Matin (1990). Significantly the longest panicle $(25.18 \mathrm{~cm})$ was found from $100 \mathrm{~kg} \mathrm{~N} \mathrm{ha}^{-1}$ and the shortest panicle $(22.56 \mathrm{~cm})$ was obtained from control (Table 02). Similar result was found from the findings of Sharma and Mishra (1986). The highest number of grains panicle-1 (120.3) was obtained from $100 \mathrm{~kg}$ $\mathrm{N}$ ha $^{-1}$ while the lowest number of grains panicle ${ }^{-1}$ (113.5) was recorded from the control. The maximum number of unfilled grains panicle-1 (18.36) was recorded from $0 \mathrm{~kg} \mathrm{~N} \mathrm{ha}^{-1}$ while the minimum number of unfilled grains panicle-1 (16.68) was found with $40 \mathrm{~kg} \mathrm{~N} \mathrm{ha}^{-1}$. Apparently the highest 1000-grain weight was found $120 \mathrm{~kg} \mathrm{~N} \mathrm{ha}^{-1}$ (25.33) and the lowest 1000-grain weight was found from the control (24.12) (Table 02). The result indicated that the increment of nitrogen increased the 1000-grain weight. Similar result was found from the findings of Lawal and Lawal (2002). Rate of nitrogen had significant effect on grain yield of BRRI dhan52. The highest grain yield (4.389 $\mathrm{t} \mathrm{ha}^{-1}$ ) was obtained from $100 \mathrm{~kg} \mathrm{~N} \mathrm{ha}^{-1}$ and the lowest grain yield (3.699 $\mathrm{t} \mathrm{ha}^{-1}$ ) was obtained

Corresponding author emails: mahaquebina@gmail.com (Haque, M. A.) / maullah09@gmail.com (Ullah, M. A.) eISSN: 2312-7945, (C) Haque et al. (2015), Research paper 
from the control. The increase in grain yield from $100 \mathrm{~kg} \mathrm{~N} \mathrm{ha}^{-1}$ might be due to the cumulative effect of the highest number of total grains panicle-1, 1000-grain weight, longest panicle length and the highest number of effective tillers hill-1 obtained from the supply of more nitrogen for the plants. Similar result was found from the findings of Singh et al. (2000). The highest straw yield (5.850 $\left.\mathrm{t} \mathrm{ha}^{-1}\right)$ was observed from $140 \mathrm{~kg} \mathrm{~N}^{-1}$. The lowest straw yield (4.587 $\left.\mathrm{t} \mathrm{ha}^{-1}\right)$ was produced in control treatment. Similar result was found from the findings of Sarker et al. (2001). With the increment of nitrogen from $0 \mathrm{~kg} \mathrm{~N} \mathrm{ha}^{-1}$ to $140 \mathrm{~kg} \mathrm{~N} \mathrm{ha}^{-1}$ biological yield was increased (Table 02). The highest biological yield (10.24 tha-1) was obtained from $100 \mathrm{~kg} \mathrm{~N} \mathrm{ha}^{-1}$ followed by $140 \mathrm{~kg} \mathrm{~N} \mathrm{ha}^{-1}$ (9.619 tha-1) and the lowest biological yield $\left(8.28 \mathrm{t} \mathrm{ha}^{-1}\right)$ was obtained from the control. The experimental results showed that the highest harvest index $(44.67 \%)$ was obtained from the control and the lowest harvest index was found (42.88\%) with $100 \mathrm{~kg} \mathrm{~N} \mathrm{ha}^{-1}$.

\section{Interaction effect of plant spacing and $\mathrm{N}$ levels}

Interaction effect of plant spacing and $\mathrm{N}$ levels showed significant variations on number of total tillers hill- $^{-1}$, effective tillers hill-1, non-effective tillers hill-1, number of filled grains panicle-1, number of unfilled grains panicle-1, grain yield and straw yield whereas plant height, 1000-grain weight and harvest index were insignificant. The highest number of effective tillers hill-1 (5.73) was produced from $100 \mathrm{~kg} \mathrm{~N} \mathrm{ha}^{-1}$ with $25 \mathrm{~cm} \times 20 \mathrm{~cm}$ spacing and the lowest one (4.03) was obtained from the control with $25 \mathrm{~cm} \times 15 \mathrm{~cm}$ spacing (Table 03). Results showed, the highest number of non-effective tillers hill-1 (2.73) was obtained from control with $25 \mathrm{~cm} \mathrm{x} 20 \mathrm{~cm}$ spacing followed by $40 \mathrm{~kg} \mathrm{~N}^{-1} \mathrm{a}^{-1}$ with $20 \mathrm{~cm} \times 15 \mathrm{~cm}$ and the lowest number of non-effective tillers hill-1 (1.67) was found from $100 \mathrm{~kg} \mathrm{~N} \mathrm{ha}^{-1}$ with $25 \mathrm{~cm} \times 20 \mathrm{~cm}$ spacing (Table 03). Number of total tillers hill-1 was significantly influenced by nitrogen rate and plant spacing. The highest number of total tillers hill-1 (7.4) was obtained from 100 $\mathrm{kg} \mathrm{N}$ ha-1 $^{-1}$ with $25 \mathrm{~cm} \times 20 \mathrm{~cm}$ spacing which was identical to $140 \mathrm{~kg} \mathrm{~N}^{-1}$ with $25 \mathrm{~cm} \times 15 \mathrm{~cm}$ spacing. The lowest number of total tiller hill-1 (6.46) was obtained from control treatment with 20 $\mathrm{cm} \times 15 \mathrm{~cm}$ spacing (Table 03). The experimental results showed that the interaction effect of rate of nitrogen and plant spacing was significant on panicle length. The longest panicle $(25.94 \mathrm{~cm})$ was obtained from $100 \mathrm{~kg} \mathrm{~N} \mathrm{ha}^{-1}$ with wider spacing of $25 \mathrm{~cm} \mathrm{x} 20 \mathrm{~cm}$, whereas the shortest panicle was $(22.25 \mathrm{~cm})$ obtained from the control with $25 \mathrm{~cm}$ x $15 \mathrm{~cm}$ (Table 03). Interaction of rate of nitrogen and plant spacing showed significant variation on the number of filled grains panicle ${ }^{-1}$. The highest number of filled grains panicle-1 (120.9) was recorded in the interaction of $100 \mathrm{~kg} \mathrm{~N} \mathrm{ha}^{-1}$ with $25 \mathrm{~cm} \mathrm{x}$ $20 \mathrm{~cm}$ spacing followed by $120 \mathrm{~kg} \mathrm{~N} \mathrm{ha}^{-1}$ with $20 \mathrm{~cm} \times 20 \mathrm{~cm}$ spacing (120.5) and the lowest one (120.9) was observed from the combination of the control with $20 \mathrm{~cm} \times 15 \mathrm{~cm}$ spacing (Table 03). Number of unfilled grains panicle was significantly influenced by the interaction between rate of nitrogen and plant spacing. Numerically the highest number of unfilled grains panicle ${ }^{-1}$ (19.04) was recorded in $0 \mathrm{~kg} \mathrm{~N}^{-1}$ with $20 \mathrm{~cm} \times 15 \mathrm{~cm}$ spacing followed by $0 \mathrm{~kg} \mathrm{~N}^{-1}$ with $25 \mathrm{~cm} \mathrm{x} 15 \mathrm{~cm}$ and the lowest one (16.33) was obtained from $100 \mathrm{~kg} \mathrm{~N}^{-1}$ with $25 \mathrm{~cm} \mathrm{x} 20 \mathrm{~cm}$ spacing (Table 03). Interaction of rate of nitrogen and spacing showed significant variation on the number of grains panicle ${ }^{-1}$. The highest number of grains panicle-1 (137.2) was recorded in the interaction of $100 \mathrm{~kg} \mathrm{~N} \mathrm{ha}^{-1}$ with $25 \mathrm{~cm}$ x $20 \mathrm{~cm}$ spacing followed by $100 \mathrm{~kg} \mathrm{~N} \mathrm{ha}^{-1}$ with $20 \mathrm{~cm}$ x15 cm spacing (137.1) and the lowest one (131.2) was observed from the combination of the control with $20 \mathrm{~cm} \times 20 \mathrm{~cm}$ spacing (Table 03). The interaction effect of different rates of nitrogen and plant spacing was not found significant in respect of 1000-gram weight. However, the 1000-grain weight ranged from 23.77 to 25.82 (Table 3). Grain yield was significantly influenced by the interaction between rate of nitrogen and plant spacing. The highest grain yield ( $\left.4.7 \mathrm{t} \mathrm{ha}^{-1}\right)$ was found from $10 \mathrm{~kg} \mathrm{~N} \mathrm{ha}^{-1}$ with $25 \mathrm{~cm} \times 20 \mathrm{~cm}$ spacing followed by $140 \mathrm{~kg} \mathrm{~N} \mathrm{ha}^{-1}$ with $25 \mathrm{~cm} \times 15 \mathrm{~cm}$ spacing and the lowest one (3.60 tha-1) was obtained from control (0 $\mathrm{kg} \mathrm{N} \mathrm{ha-1)} \mathrm{with} 20 \mathrm{~cm} \times 15 \mathrm{~cm}$ spacing (Table 03). Miah et al. (1990) previous study supported the results. From the results discussed above, it can be concluded that Transplant aman rice cv. BRRI dhan 52 grown under $100 \mathrm{~kg} \mathrm{~N}^{-1}$ with $25 \mathrm{~cm}$ x $20 \mathrm{~cm}$ spacing emerged out as a promising practice in order to get the desired grain yield. Interaction of rate of nitrogen and plant spacing significantly influenced straw yield. The highest straw yield $\left(6.25 \mathrm{t} \mathrm{ha}^{-1}\right)$ was recorded from $100 \mathrm{~kg} \mathrm{~N} \mathrm{ha}^{-1}$ with $25 \mathrm{~cm} \times 20 \mathrm{~cm}$ spacing and the lowest straw yield ( $\left.4.25 \mathrm{t} \mathrm{ha}^{-1}\right)$ was obtained from control treatment $\left(0 \mathrm{~kg} \mathrm{~N} \mathrm{ha}^{-1}\right)$ and $20 \mathrm{~cm} \times 15 \mathrm{~cm}$ spacing (Table 03). Interaction of rate of nitrogen and plant spacing significantly influenced the biological yield. The highest biological yield (10.99) t ha $^{-1}$ was recorded from $100 \mathrm{~kg} \mathrm{~N}^{-1}$ with $25 \mathrm{~cm} \times 20 \mathrm{~cm}$ spacing and the lowest biological yield $(67.850 \mathrm{t}$ $\left.\mathrm{ha}^{-1}\right)$ was obtained from control treatment $\left(0 \mathrm{~kg} \mathrm{~N} \mathrm{ha}^{-1}\right)$ with $25 \mathrm{~cm}$ x $20 \mathrm{~cm}$ spacing (Table 03).

Corresponding author emails: mahaquebina@gmail.com (Haque, M. A.) / maullah09@gmail.com (Ullah, M. A.) eISSN: 2312-7945, (C) Haque et al. (2015), Research paper 
Interactions of rate of nitrogen and plant spacing not significantly influenced the harvest index. Harvest index ranged from $(42.17 \%)$ to $(45.86 \%)$.

\section{Conclusion}

The highest plant height, number of total and effective tillers hill-1 ${ }^{-1}$ was observed in wider spacing, 25 $\mathrm{cm} \times 20 \mathrm{~cm}$ with $\mathrm{N} 100 \mathrm{~kg} \mathrm{ha}^{-1}$. On the contrary, the lowest one was recorded in narrower spacing 20 $\mathrm{cm} \times 15 \mathrm{~cm}$ with no nitrogen. Based on the experimental results, it may be concluded that $25 \mathrm{~cm} \times 20$ $\mathrm{cm}$ spacing with $100 \mathrm{~kg} \mathrm{~N} \mathrm{ha}^{-1}$ would be the best regarding yield and yield attributes of BRRI dhan52 in aman season.

\section{Acknowledgement}

I would like to express my sincere appreciation and indebtedness to my supervisors, teachers and the staff members of the Agronomy Department, Bangladesh Agricultural University, Mymensingh.

\section{References}

[1]. Anonymous, (2009). Monthly Statistical Bulletin of Bangladesh, June 2006. Bangladesh Bureau of Statistics, Statistics Division, Ministry of Planning, Govt. of the People's Republic of Bangladesh, Dhaka. p. 54.

[2]. BBS (Bangladesh Bureau of Statistics), (2011). Statistical Year Book of Bangladesh, August. Bangladesh Bur. of Stat. Stat. Div., Min. Plan., Govt. Peoples Repub., Bangladesh, Dhaka. p. 136140.

[3]. BRRI (Bangladesh Rice Research Institute), (1999). Annual Report for 1998. Bangladesh Rice Res. Inst., Joydebpur, Gazipur. pp. 152-158.

[4]. BRRI (Bangladesh Rice Research Institute) (1990). Annual Internal Review Report 1989. Bangladesh Rice Res. Inst., Joydebpur, Gazipur. 11:1-19.

[5]. Chopra, N. K., and Chopra, N. (2004). Seed yield and quality of 'pusa 44'rice (Oryza sativa) as influenced by nitrogen fertilizer and row spacing. India. J. Agril. Sci. 74(3): 144-146.

[6]. Gomez, K. A. and Gomez, A. A. (1984). Statistical Procedure for Agricultural Research. Intl. Rice Res. Inst., John Wiley and Sons. New York, Chickester, Brisbane, Toronto, Singapore. pp. 1-34.

[7]. Hamid. M. A. (1991). A Data Base on Agricultural and Food Grains in Bangladesh (1947-48 to 1989-90). Ayesha Akhtar, 606 North Shajahanpur, Dhaka, Bangladesh. pp. 30-35.

[8]. Kiron, G. M. (2003). Azker Bishaw. Primiar publication 77/F-1, East Rampura, Dhaka-1219. P. 150.

[9]. Miah, M. N. H, Karim, M. A, Rahman, M. S. and Islam, M. S. (1990). Performance of Nigersail mutants under different row spacing. Bangladesh J. Training Dcv. 3(2): 31-34.

[10]. Hossain, S. M. A. and Islam, M. S. (1986). Fertilizer management in Bangladesh., Adv. Agron. Res. in Joydebpur, Gazipur. pp. 48-54.

[11]. Idris, M. and Matin, M. A. (1990). Response of four exotic strains of Aman rice to urea. Bangladesh J. Agril. Sci .17(2): 271-275, pp. 87-91.

[12]. Sharma, M. L. and Mishra, V. R. (1986). Effect of fertilizer nitrogen and algal inoculation on rice corp. Madras Agric. J. 71(2): 155-159.

[13]. Lawal, M. I. and Lawal, A. B. (2002). Influence of nitrogen rate and placement methods on growth and yield of rice (Oryza sativa L.) at Kadawa. Nigerian J. 23(3): 403-441.

[14]. Singh, M. K., Thakur, R., Verma, U. N., Upasami, R. R. and Pal, S. K. (2000). Effect of planting time and nitrogen on production potential of Basmati rice (Oryza sativa) cultivars in Bihar Plateau. Indian J. Agron. 45(2): 303-303.

[15]. Sarker, M. A. I. (2001). Effect of row spacing and number of seedlings hill-1 on the performance of hybrid rice, Sonar Bangla-1, M.S. Thesis, Dept. Agron., Bangladesh Agril. Univ., Mymensingh. p. 52. 
[16]. UNDP/FAO, (1988). Land resources appraisal of bangladesh for agricultural development report No. 2. Agro-ecological regions of Bangladesh. United Nations Development Program and Food and Agriculture Organization, pp: 212-221.

[17]. Verma, A. K., Pandey, N. and Tripathi, S. (2002). Effect of transplanting spacing and number of seedlings on productive tillers, spikelets sterility, grain yield and harvest index of hybrid rice. Intl. Rice Res. Notes 57: 1-51. 
Table 01. Mean effect of plant spacing on plant characters and yields of Aman rice BRRI Dhan52

\begin{tabular}{|c|c|c|c|c|c|c|c|c|c|c|c|c|c|}
\hline $\begin{array}{l}\text { Plant } \\
\text { Spacing } \\
(\mathrm{cm})\end{array}$ & $\begin{array}{l}\text { Plant } \\
\text { height } \\
(\mathrm{cm})\end{array}$ & $\begin{array}{l}\text { Total } \\
\text { tillers hill-1 } \\
\text { (no.) }\end{array}$ & $\begin{array}{c}\text { Effective } \\
\text { tillers hill-1 } \\
\text { (no.) }\end{array}$ & $\begin{array}{c}\text { Non- } \\
\text { effective } \\
\text { tillers hill-1 } \\
\text { (no.) }\end{array}$ & $\begin{array}{c}\text { Panicle } \\
\text { Length } \\
(\mathrm{cm})\end{array}$ & $\begin{array}{c}\text { Filled } \\
\text { grains } \\
\text { panicle-1 } \\
\text { (no.) } \\
\end{array}$ & $\begin{array}{l}\text { Unfilled } \\
\text { grains } \\
\text { panicle-1 } \\
\text { (no.) } \\
\end{array}$ & $\begin{array}{c}\text { Total } \\
\text { grains } \\
\text { panicle-1 } \\
\text { (no.) } \\
\end{array}$ & $\begin{array}{c}1000 \\
\text { grains } \\
\text { Wt.(g) }\end{array}$ & $\begin{array}{l}\text { Grain } \\
\text { yield } \\
\text { (t ha-1) }\end{array}$ & $\begin{array}{l}\text { Straw } \\
\text { yield } \\
\left(\text { t ha-1) }^{-1}\right.\end{array}$ & $\begin{array}{l}\text { Biologica } \\
\text { l Yield } \\
\left(\mathrm{t} \mathrm{ha}^{-1}\right)\end{array}$ & $\begin{array}{c}\text { Harvest } \\
\text { index } \\
(\%)\end{array}$ \\
\hline $25 \times 20$ & $108.30 \mathrm{a}$ & $7.127 \mathrm{a}$ & $5.29 \mathrm{a}$ & $1.840 \mathrm{c}$ & $24.63 a$ & $117.8 \mathrm{a}$ & $16.94 \mathrm{c}$ & $134.7 \mathrm{a}$ & $24.88 a$ & $4.247 a$ & $5.448 a$ & $9.695 a$ & $43.83 b c$ \\
\hline $25 \times 15$ & $104.40 \mathrm{~b}$ & $7.145 a$ & $4.99 c$ & $2.158 \mathrm{a}$ & $22.78 c$ & $116.3 c$ & $17.68 \mathrm{~b}$ & $134.0 \mathrm{c}$ & 24.68ab & $4.004 c$ & $5.056 c$ & $9.059 c$ & $44.26 \mathrm{ab}$ \\
\hline $20 \times 20$ & $106.80 \mathrm{a}$ & 7.161a & $5.13 b$ & $2.028 \mathrm{~b}$ & $23.49 \mathrm{~b}$ & $117.2 \mathrm{~b}$ & $17.15 \mathrm{c}$ & $134.3 b$ & $24.61 \mathrm{ab}$ & $4.084 b$ & $5.317 \mathrm{~b}$ & $9.401 b$ & $43.46 c$ \\
\hline $20 \times 15$ & $102.10 \mathrm{c}$ & $6.737 b$ & $4.60 \mathrm{~d}$ & $2.13 \mathrm{a}$ & $22.58 c$ & $116.0 \mathrm{c}$ & $18.12 \mathrm{a}$ & $134.1 \mathrm{c}$ & $24.41 b$ & $3.917 d$ & $4.870 \mathrm{~d}$ & $8.787 d$ & $44.63 a$ \\
\hline $\begin{array}{c}\text { Level of } \\
\text { significance }\end{array}$ & $* *$ & $* *$ & $* *$ & $* *$ & $* *$ & $* *$ & $* *$ & $* *$ & $*$ & $* *$ & $* *$ & $* *$ & $* *$ \\
\hline$C V(\%)$ & 2.04 & 2.01 & 2.13 & 4.25 & 2.63 & 0.45 & 2.49 & 0.50 & 1.78 & 2.02 & 2.08 & 1.45 & 2.22 \\
\hline
\end{tabular}

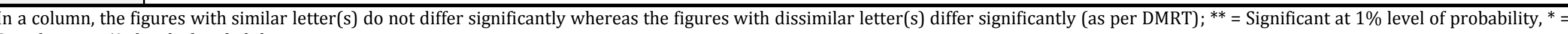
Significant at $5 \%$ level of probability

Table 02. Mean effect of different levels of $\mathrm{N}$ on plant characters and yields of Aman rice Var. BRRI dhan52

\begin{tabular}{|c|c|c|c|c|c|c|c|c|c|c|c|c|c|}
\hline $\begin{array}{l}\text { Nitrogen } \\
\text { Level } \\
\left(\mathrm{kg} \mathrm{ha}^{-1}\right)\end{array}$ & $\begin{array}{l}\text { Plant } \\
\text { height } \\
(\mathrm{cm})\end{array}$ & $\begin{array}{l}\text { Total } \\
\text { tillers hill-1 } \\
\text { (no.) }\end{array}$ & $\begin{array}{l}\text { Effective } \\
\text { tillers hill-1 } \\
\text { (no.) }\end{array}$ & $\begin{array}{c}\text { Non- } \\
\text { effective } \\
\text { tillers hill- } \\
1 \text { (no.) } \\
\end{array}$ & $\begin{array}{l}\text { Panicle } \\
\text { length } \\
(\mathrm{cm})\end{array}$ & $\begin{array}{c}\text { Filled } \\
\text { grains } \\
\text { panicle-1 } \\
\text { (no.) } \\
\end{array}$ & $\begin{array}{l}\text { Unfilled } \\
\text { grains } \\
\text { panicle-1 } \\
\text { (no.) } \\
\end{array}$ & $\begin{array}{c}\text { Total } \\
\text { grains } \\
\text { panicle-1 } \\
\text { (no.) } \\
\end{array}$ & $\begin{array}{c}1000 \\
\text { grain } \\
\text { Wt.(g) }\end{array}$ & $\begin{array}{l}\text { Grain } \\
\text { yield } \\
\left(\mathrm{t} \mathrm{ha}^{-1}\right)\end{array}$ & $\begin{array}{l}\text { Straw } \\
\text { yield } \\
\left(\text { t ha-1) }^{-1}\right.\end{array}$ & $\begin{array}{c}\text { Biological } \\
\text { yield } \\
\left(\mathrm{t} \mathrm{ha}^{-1}\right)\end{array}$ & $\begin{array}{c}\text { Harvest } \\
\text { index } \\
(\%)\end{array}$ \\
\hline 0 & $102.80 \mathrm{~d}$ & $6.82 \mathrm{c}$ & $4.36 \mathrm{e}$ & $2.46 \mathrm{a}$ & $22.56 \mathrm{~d}$ & $113.5 \mathrm{e}$ & $18.36 a$ & $131.90 \mathrm{~d}$ & $24.12 \mathrm{c}$ & $3.70 \mathrm{e}$ & $4.59 \mathrm{e}$ & $8.285 \mathrm{e}$ & $44.67 \mathrm{a}$ \\
\hline 40 & $104.20 \mathrm{~cd}$ & $6.89 c$ & $4.79 d$ & $2.10 \mathrm{~b}$ & $22.67 \mathrm{~cd}$ & $115.1 d$ & $17.97 \mathrm{~b}$ & 133.10c & $24.47 \mathrm{bc}$ & $3.89 \mathrm{~d}$ & $4.90 \mathrm{~d}$ & $8.792 d$ & $44.26 \mathrm{a}$ \\
\hline 80 & $104.90 \mathrm{bc}$ & $7.10 \mathrm{~b}$ & $5.10 \mathrm{c}$ & $2.0 \mathrm{c}$ & $23.10 b c$ & $117.2 \mathrm{c}$ & $17.49 \mathrm{c}$ & $134.70 \mathrm{~b}$ & $24.55 b$ & $4.09 c$ & $5.15 c$ & $9.242 \mathrm{c}$ & $44.28 \mathrm{a}$ \\
\hline 100 & $106.30 \mathrm{~b}$ & 7.15ab & $5.45 a$ & $1.70 \mathrm{e}$ & $25.18 a$ & $120.3 a$ & $16.68 d$ & $137.0 \mathrm{a}$ & $25.33 a$ & $4.39 a$ & $5.85 a$ & $10.24 a$ & $42.88 b$ \\
\hline 140 & $108.70 \mathrm{a}$ & $7.25 \mathrm{a}$ & $5.32 \mathrm{~b}$ & $1.93 \mathrm{~d}$ & $23.36 \mathrm{~b}$ & 118.0b & $16.88 d$ & $134.90 \mathrm{~b}$ & $24.76 b$ & $4.24 b$ & $5.37 \mathrm{~b}$ & $9.619 \mathrm{~b}$ & $44.12 \mathrm{a}$ \\
\hline $\begin{array}{c}\text { Level of } \\
\text { significance }\end{array}$ & ** & $* *$ & $* *$ & ** & $* *$ & $* *$ & $* *$ & $* *$ & $* *$ & $* *$ & $* *$ & $* *$ & $* *$ \\
\hline$C V(\%)$ & 2.04 & 2.01 & 2.13 & 4.25 & 2.63 & 0.45 & 2.49 & 0.50 & 1.78 & 2.02 & 2.08 & 1.45 & 2.22 \\
\hline
\end{tabular}

Corresponding author emails: mahaquebina@gmail.com (Haque, M. A.) / maullah09@gmail.com (Ullah, M. A.) 
Table 03. Interaction effect of plant spacing and different nitrogen levels on plant characters and yields of Aman rice BRRI Dhan52

\begin{tabular}{|c|c|c|c|c|c|c|c|c|c|c|c|c|c|}
\hline $\begin{array}{l}\text { Spacing } \mathrm{x} \\
\text { Rate of N }\end{array}$ & $\begin{array}{l}\text { Plant } \\
\text { height } \\
(\mathrm{cm})\end{array}$ & $\begin{array}{c}\text { Effective } \\
\text { tillers hill-1 } \\
\text { (no.) }\end{array}$ & $\begin{array}{l}\text { Non- } \\
\text { effective } \\
\text { tillers hill-1 } \\
\text { (no.) }\end{array}$ & $\begin{array}{l}\text { Total } \\
\text { tillers } \\
\text { hill- }^{-1} \\
\text { (no.) } \\
\end{array}$ & $\begin{array}{l}\text { Panicle } \\
\text { length } \\
(\mathrm{cm})\end{array}$ & $\begin{array}{c}\text { Filled grains } \\
\text { panicle-1 } \\
\text { (no.) }\end{array}$ & $\begin{array}{l}\text { Unfilled } \\
\text { grains } \\
\text { panicle }{ }^{-1} \\
\text { (no.) } \\
\end{array}$ & $\begin{array}{c}\text { Total } \\
\text { grains } \\
\text { panicle-1 } \\
\text { (no.) }\end{array}$ & $\begin{array}{l}\text { Weight } \\
\text { of } 1000 \\
\text { grains } \\
\text { (g) }\end{array}$ & $\begin{array}{l}\text { Grain } \\
\text { yield } \\
\text { (t ha-1) }\end{array}$ & $\begin{array}{l}\text { Straw } \\
\text { yield } \\
\left(\text { t ha-1) }^{-1}\right.\end{array}$ & $\begin{array}{c}\text { Biological } \\
\text { yield } \\
\left(\mathrm{t} \mathrm{ha}^{-1}\right)\end{array}$ & $\begin{array}{c}\text { Harvest } \\
\text { index } \\
(\%)\end{array}$ \\
\hline $\mathrm{S}_{1} \mathrm{~N}_{0}$ & 105.5 & $4.69 \mathrm{efg}$ & $2.20 \mathrm{c}$ & $6.88 \mathrm{~d}-\mathrm{g}$ & $22.86 \mathrm{~d}$ & $114.4 \mathrm{f}$ & $17.23 \mathrm{~d}-\mathrm{h}$ & $131.7 \mathrm{gh}$ & 24.40 & $3.85 \mathrm{hi}$ & $4.85 \mathrm{hi}$ & $8.71 \mathrm{kl}$ & 44.25 \\
\hline $\mathrm{S}_{1} \mathrm{~N}_{1}$ & 106.4 & $4.96 \mathrm{~cd}$ & $1.93 \mathrm{ef}$ & $6.89 \mathrm{~d}-\mathrm{g}$ & $23.06 \mathrm{~d}$ & $115.6 \mathrm{e}$ & $17.30 \mathrm{~d}-\mathrm{h}$ & $132.9 \mathrm{~d}-\mathrm{g}$ & 24.62 & $4.03 \mathrm{fg}$ & $5.21 \mathrm{ef}$ & $9.24 \mathrm{hi}$ & 43.58 \\
\hline $\mathrm{S}_{1} \mathrm{~N}_{2}$ & 107.4 & $5.40 \mathrm{~b}$ & $1.73 \mathrm{gh}$ & $7.13 \mathrm{a}-\mathrm{d}$ & $24.55 \mathrm{c}$ & $118.5 \mathrm{c}$ & $17.23 \mathrm{~d}-\mathrm{h}$ & $135.8 \mathrm{bc}$ & 24.74 & $4.22 \mathrm{bcd}$ & $5.42 \mathrm{~d}$ & $9.64 \mathrm{def}$ & 43.83 \\
\hline $\mathrm{S}_{1} \mathrm{~N}_{3}$ & 112.6 & $5.73 \mathrm{a}$ & $1.67 \mathrm{~h}$ & $7.40 \mathrm{a}$ & $27.94 \mathrm{a}$ & $120.9 \mathrm{a}$ & $16.33 \mathrm{i}$ & $137.2 \mathrm{a}$ & 25.82 & $4.74 \mathrm{a}$ & $6.25 \mathrm{a}$ & $10.99 \mathrm{a}$ & 43.15 \\
\hline $\mathrm{S}_{1} \mathrm{~N}_{4}$ & 109.4 & $5.67 \mathrm{a}$ & $1.67 \mathrm{~h}$ & $7.33 \mathrm{ab}$ & $24.75 \mathrm{c}$ & $119.6 \mathrm{~b}$ & $16.63 \mathrm{~g}-\mathrm{i}$ & $136.2 \mathrm{abc}$ & 24.80 & $4.37 \mathrm{~b}$ & $5.50 \mathrm{~d}$ & $9.87 \mathrm{~cd}$ & 44.32 \\
\hline $\mathrm{S}_{2} \mathrm{~N}_{0}$ & 102.4 & $4.33 \mathrm{i}$ & $2.73 \mathrm{a}$ & 7.06 b-e & $22.40 \mathrm{~d}$ & $113.2 \mathrm{~g}$ & $19.04 \mathrm{ab}$ & $132.3 \mathrm{fgh}$ & 24.40 & $3.67 \mathrm{j}$ & $4.42 \mathrm{kl}$ & $8.08 n$ & 45.38 \\
\hline $\mathrm{S}_{2} \mathrm{~N}_{1}$ & 103.4 & $4.80 \mathrm{def}$ & $2.13 \mathrm{~cd}$ & $6.93 \mathrm{~d}-\mathrm{g}$ & $22.45 \mathrm{~d}$ & $114.8 \mathrm{ef}$ & $18.31 \mathrm{bc}$ & $133.1 \mathrm{def}$ & 24.44 & $3.87 \mathrm{hi}$ & $4.70 \mathrm{ij}$ & 8.571 & 45.15 \\
\hline $\mathrm{S}_{2} \mathrm{~N}_{2}$ & 103.7 & $5.0 \mathrm{c}$ & $2.13 \mathrm{~cd}$ & $7.13 \mathrm{a}-\mathrm{d}$ & $22.57 \mathrm{~d}$ & $116.6 \mathrm{~d}$ & $17.53 c-f$ & $134.1 \mathrm{~d}$ & 24.51 & $4.06 \mathrm{efg}$ & $5.08 \mathrm{fg}$ & $9.14 \mathrm{hi}$ & 44.42 \\
\hline $\mathrm{S}_{2} \mathrm{~N}_{3}$ & 108.4 & $5.47 \mathrm{~b}$ & $1.73 \mathrm{~h}$ & $7.20 \mathrm{a}-\mathrm{c}$ & $23.42 \mathrm{~d}$ & $119.9 \mathrm{~b}$ & $16.58 \mathrm{ghi}$ & $136.5 \mathrm{abc}$ & 25.34 & $4.25 \mathrm{bcd}$ & $5.75 \mathrm{c}$ & $10.00 \mathrm{c}$ & 42.50 \\
\hline $\mathrm{S}_{2} \mathrm{~N}_{4}$ & 104.0 & $5.33 \mathrm{~b}$ & $2.07 \mathrm{cde}$ & $7.40 \mathrm{a}$ & $23.06 \mathrm{~d}$ & $117.0 \mathrm{~d}$ & $16.95 \mathrm{e}-\mathrm{i}$ & $134.0 \mathrm{~d}$ & 24.73 & $4.17 \mathrm{c}-\mathrm{f}$ & $5.33 \mathrm{de}$ & $9.50 \mathrm{fg}$ & 43.86 \\
\hline $\mathrm{S}_{3} \mathrm{~N}_{0}$ & 102.9 & $4.40 \mathrm{hi}$ & $2.47 \mathrm{~b}$ & $6.87 \mathrm{~d}-\mathrm{g}$ & $22.71 \mathrm{~d}$ & $113.4 \mathrm{~g}$ & $17.78 \mathrm{cde}$ & $131.2 \mathrm{~h}$ & 23.92 & $3.67 \mathrm{j}$ & 4.82 hi & $8.49 \mathrm{~lm}$ & 43.21 \\
\hline $\mathrm{S}_{3} \mathrm{~N}_{1}$ & 106.0 & 4.87 cde & $2.13 \mathrm{~cd}$ & $7.0 \mathrm{c}-\mathrm{f}$ & $22.77 \mathrm{~d}$ & $115.3 \mathrm{ef}$ & $17.40 \mathrm{~d}-\mathrm{g}$ & 132.7 efg & 24.46 & $3.92 \mathrm{gh}$ & $5.11 \mathrm{fg}$ & $9.03 \mathrm{ij}$ & 43.37 \\
\hline $\mathrm{S}_{3} \mathrm{~N}_{2}$ & 106.9 & $5.33 \mathrm{~b}$ & $2.0 \mathrm{def}$ & $7.33 \mathrm{ab}$ & $22.83 \mathrm{~d}$ & $118.0 \mathrm{c}$ & $17.36 \mathrm{~d}-\mathrm{g}$ & $135.3 \mathrm{c}$ & 24.55 & $4.16 \mathrm{c}-\mathrm{f}$ & $5.17 \mathrm{ef}$ & $9.33 \mathrm{gh}$ & 44.59 \\
\hline $\mathrm{S}_{3} \mathrm{~N}_{3}$ & 109.7 & $5.67 \mathrm{a}$ & $1.67 \mathrm{~h}$ & $7.33 \mathrm{a}$ & $26.09 \mathrm{~b}$ & $120.5 \mathrm{ab}$ & $16.50 \mathrm{hi}$ & $137.0 \mathrm{ab}$ & 25.35 & $4.36 \mathrm{~b}$ & $5.98 \mathrm{~b}$ & $10.34 \mathrm{~b}$ & 45.94 \\
\hline $\mathrm{S}_{3} \mathrm{~N}_{4}$ & 108.2 & $5.40 \mathrm{~b}$ & $1.87 \mathrm{fg}$ & $7.27 \mathrm{ab}$ & $23.07 \mathrm{~d}$ & $118.7 \mathrm{c}$ & $16.70 \mathrm{f}-\mathrm{i}$ & $135.4 \mathrm{c}$ & 24.78 & $4.31 \mathrm{bc}$ & $5.50 \mathrm{~d}$ & 9.81 cde & 43.94 \\
\hline $\mathrm{S}_{4} \mathrm{~N}_{0}$ & 100.3 & $4.03 \mathrm{j}$ & $2.43 \mathrm{~b}$ & $6.46 \mathrm{~h}$ & $22.25 \mathrm{~d}$ & $112.9 \mathrm{~g}$ & $19.40 \mathrm{a}$ & $132.3 \mathrm{fgh}$ & 23.77 & $3.60 \mathrm{j}$ & 4.251 & $7.85 \mathrm{o}$ & 42.17 \\
\hline $\mathrm{S}_{4} \mathrm{~N}_{1}$ & 101.3 & $4.53 \mathrm{gh}$ & $2.20 \mathrm{c}$ & $6.73 \mathrm{fg}$ & $22.39 \mathrm{~d}$ & 114.7 ef & $18.86 \mathrm{ab}$ & $133.6 \mathrm{de}$ & 24.34 & $3.74 \mathrm{ij}$ & $4.58 \mathrm{jk}$ & $8.32 \mathrm{~m}$ & 44.95 \\
\hline $\mathrm{S}_{4} \mathrm{~N}_{2}$ & 101.5 & $4.67 \mathrm{fg}$ & $2.16 \mathrm{c}$ & $6.83 \mathrm{e}-\mathrm{g}$ & $22.45 \mathrm{~d}$ & $115.6 \mathrm{e}$ & $17.82 \mathrm{~cd}$ & $133.4 \mathrm{def}$ & 24.41 & $3.92 \mathrm{gh}$ & $4.93 \mathrm{gh}$ & $8.85 \mathrm{jk}$ & 44.28 \\
\hline $\mathrm{S}_{4} \mathrm{~N}_{3}$ & 104.1 & $4.93 \mathrm{~cd}$ & $1.73 \mathrm{gh}$ & $6.66 \mathrm{gh}$ & $23.28 \mathrm{~d}$ & $119.8 \mathrm{~b}$ & $17.30 \mathrm{~d}-\mathrm{h}$ & $137.1 \mathrm{a}$ & 24.81 & 4.20 cde & $5.42 \mathrm{~d}$ & $9.62 \mathrm{ef}$ & 43.69 \\
\hline $\mathrm{S}_{4} \mathrm{~N}_{4}$ & 103.5 & 4.87 cde & $2.13 \mathrm{~cd}$ & $7.0 \mathrm{c}-\mathrm{f}$ & $22.55 \mathrm{~d}$ & $116.9 \mathrm{~d}$ & $17.23 \mathrm{~d}-\mathrm{h}$ & $134.1 \mathrm{~d}$ & 24.71 & $4.12 \mathrm{def}$ & $5.17 \mathrm{ef}$ & $9.29 \mathrm{gh}$ & 44.35 \\
\hline $\begin{array}{c}\text { Level of } \\
\text { significance }\end{array}$ & $N S$ & $* *$ & $* *$ & $*$ & $* *$ & $* *$ & $*$ & $* *$ & $N S$ & $* *$ & $* *$ & $* *$ & $N S$ \\
\hline$C V(\%)$ & 2.04 & 2.13 & 4.25 & 2.01 & 2.63 & 0.45 & 2.49 & 0.50 & 1.78 & 2.02 & 2.08 & 1.45 & 2.22 \\
\hline
\end{tabular}

In a column, the figures with similar letter (s) do not differ significantly whereas the figures with dissimilar letter (s) differ significantly (as per DMRT)

$\mathrm{N}_{0}=0 \mathrm{~kg} \mathrm{~N}^{-1}, \mathrm{~N}_{1}=40 \mathrm{~kg} \mathrm{~N}^{-1}, \mathrm{~N}_{2}=80 \mathrm{~kg} \mathrm{~N}^{-1} \mathrm{ha}^{-1} \mathrm{~N}_{3}=100 \mathrm{~kg} \mathrm{~N}^{-1}, \mathrm{~N}_{4}=140 \mathrm{~kg} \mathrm{~N}^{-1}$.

$\mathrm{S}_{1}=25 \mathrm{~cm} \times 20 \mathrm{~cm}, \mathrm{~S}_{2}=25 \mathrm{~cm} \times 15 \mathrm{~cm}, \mathrm{~S}_{3}=20 \mathrm{~cm} \times 20 \mathrm{~cm}, \mathrm{~S}_{4}=20 \mathrm{~cm} \times 15 \mathrm{~cm}$

** = Significant at $1 \%$ level of probability; ${ }^{*}=$ Significant at $5 \%$ level of probability, NS = Not significant 